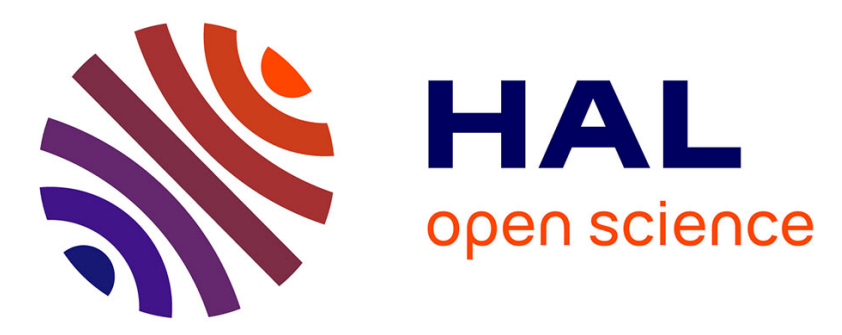

\title{
High-resolution Pleistocene diatom biostratigraphy of Site 983 and correlations with isotope stratigraphy
}

\author{
N. Koç, D.A. Hodell, H. Kleiven, L. Labeyrie
}

\section{To cite this version:}

N. Koç, D.A. Hodell, H. Kleiven, L. Labeyrie. High-resolution Pleistocene diatom biostratigraphy of Site 983 and correlations with isotope stratigraphy. Proceedings of the Ocean Drilling Program, 162 Scientific Results, 162, Ocean Drilling Program, 1999, Proceedings of the Ocean Drilling Program, 10.2973/odp.proc.sr.162.035.1999 . hal-02958678

\section{HAL Id: hal-02958678 \\ https://hal.science/hal-02958678}

Submitted on 26 Jan 2021

HAL is a multi-disciplinary open access archive for the deposit and dissemination of scientific research documents, whether they are published or not. The documents may come from teaching and research institutions in France or abroad, or from public or private research centers.
L'archive ouverte pluridisciplinaire HAL, est destinée au dépôt et à la diffusion de documents scientifiques de niveau recherche, publiés ou non, émanant des établissements d'enseignement et de recherche français ou étrangers, des laboratoires publics ou privés. 


\title{
4. HIGH-RESOLUTION PLEISTOCENE DIATOM BIOSTRATIGRAPHY OF SITE 983 AND CORRELATIONS WITH ISOTOPE STRATIGRAPHY ${ }^{1}$
}

\author{
Nalân Koç, ${ }^{2,3}$ David A. Hodell, ${ }^{4}$ Helga Kleiven, ${ }^{2}$ and Laurent Labeyrie ${ }^{5}$
}

\begin{abstract}
High accumulation rates and the presence of well-preserved, abundant diatoms in Site 983 sediments from the Gardar Drift gave us the opportunity to refine the Pleistocene diatom biostratigraphic resolution of the high-latitude North Atlantic. Eight Pleistocene diatom datum events are identified and, for the first time, tied directly to the oxygen isotope record and paleomagnetic stratigraphy of Site 983. These datum events are (1) the last occurrence (LO) of Proboscia curvirostris at $0.3 \mathrm{Ma}$, (2) the LO of Thalassiosira jouseae at $0.3 \mathrm{Ma},(3)$ the LO of Nitzschia reinholdii at $0.6 \mathrm{Ma}$, (4) the LO of Nitzschia fossilis at $0.68 \mathrm{Ma}$, (5) the LO of Nitzschia seminae at $0.84 \mathrm{Ma}$, (6) the first occurrence (FO) of N. seminae at $1.25 \mathrm{Ma}$, (7) the FO of Proboscia curvirostris at $1.53 \mathrm{Ma}$, and (8) the FO of Pseudoeunotia doliolus at $1.89 \mathrm{Ma}$. Most of these datums are found to be synchronous between the middle and high latitudes of the North Atlantic and the North Pacific. On the basis of these datums, four highlatitude North Atlantic diatom zones are proposed for the Pleistocene. The record of diatom abundance and preservation at Site 983 gives evidence for the influence of fluctuating Pleistocene climatic conditions on diatom productivity in the high-latitude North Atlantic.
\end{abstract}

\section{INTRODUCTION}

The Cenozoic diatom biostratigraphy of the North Atlantic Ocean up to $60^{\circ} \mathrm{N}$ was established on the basis of material from Deep Sea Drilling Program (DSDP) Legs 81 and 94 (Baldauf, 1984, 1986, 1987). Diatoms were generally present at DSDP sites located in middle latitudes $\left(35^{\circ} \mathrm{N}-50^{\circ} \mathrm{N}\right)$ of the North Atlantic during the Pleistocene. However, at higher latitudes (DSDP Sites 552-555 and 610), Pleistocene sediments were generally devoid of diatoms (Fig. 1) (Baldauf, 1984, 1986, 1987). Baldauf (1984) showed that in Hole $552 \mathrm{~A}$, at least during the late Quaternary, changes in the abundance of diatoms corresponded to fluctuations of the oxygen isotope curve, indicating a climatic control on the abundance of diatoms. Partly because of the effect of late Quaternary climatic fluctuations on diatom abundances and partly because of sampling resolutions, a Pleistocene diatom zonation for the high-latitude North Atlantic could not be obtained.

Sediments recovered during Ocean Drilling Program (ODP) Legs 151 and 152 to the high-latitude North Atlantic have provided us with more information on the temporal and spatial distribution of diatomrich sediments (Koç and Scherer, 1996; Koç and Flower, 1998; Scherer and Koç, 1996; Stabell and Koç, 1996). High-resolution diatom biostratigraphy and abundance investigations of Site 919 confirmed the influence of Pleistocene glacial-interglacial climatic fluctuations on the diatom abundance of high-latitude North Atlantic sediments for the last $1 \mathrm{Ma}$ (Koç and Flower, 1998). Furthermore, three diatom datum events (last occurrences [LO] of Thalassiosira nidulus, Proboscia curvirostris, and Neodenticula seminae) were identified and, for the first time, tied directly to the oxygen isotope record of Site 919, making it possible to suggest a more detailed Pleistocene diatom zonation for the high-latitude North Atlantic.

${ }^{\prime}$ Raymo, M.E., Jansen, E., Blum, P., and Herbert, T.D. (Eds.), 1999. Proc. ODP, Sci. Results, 162: College Station, TX (Ocean Drilling Program). way.

${ }^{2}$ Department of Geology, University of Bergen, Allégt. 41, N-5007 Bergen, Nor-

${ }^{3}$ Present address: Norwegian Polar Institute, N-9005 Troms $\varnothing$, Norway.

Nalan.Koc@n.polar.no

${ }^{4}$ Department of Geology, University of Florida, 1112 Turlington Hall, Gainesville, FL 32611, U.S.A.

${ }^{5}$ Centres des Faibles Radioactivites, CNRS-CEA, Gif sur Yvette, France.
During Leg 162, in combination with Leg 151, broad north-south and east-west transects were drilled to monitor spatial paleoclimatic variability (Jansen, Raymo, Blum, et al., 1996). To study the evolution of millennial-scale climate variability in the North Atlantic, several high-accumulation-rate sites were drilled on sediment drifts. Site $983\left(60^{\circ} 24.20^{\prime} \mathrm{N}, 23^{\circ} 38.437^{\prime} \mathrm{W}\right)$ is located on the Gardar Drift at a water depth of $\sim 1985 \mathrm{~m}$ on the eastern flank of the Reykjanes Ridge (Fig. 1). Recovery of sediment from the holes exceeds 100\%. Both calcium carbonate and siliceous microfossils are well preserved throughout the recovered sequence. There is no sedimentological evidence for erosion or winnowing (Jansen, Raymo, Blum, et al., 1996). Because of the presence of well-preserved diatoms and high sedimentation rates at this site, Site 983 was chosen for detailed study to refine the middle- and high-latitude North Atlantic Pleistocene diatom biostratigraphy.

\section{METHODS}

One sample from each core section $(1.5 \mathrm{~m})$ of Hole 983A was analyzed for its diatom content. Approximately $1-2 \mathrm{~g}$ of dry sample was placed in a $250-\mathrm{mL}$ beaker and 10 drops of $37 \% \mathrm{HCl}$ acid were added. After waiting for at least $15 \mathrm{~min}$ for the reaction to stop, 10 drops of $30 \%$ hydrogen peroxide were added. The sample was gently heated until the liquid became light yellow. The acidity of the sample was diluted by centrifuging it with distilled water until a $\mathrm{pH}$ of 7 was achieved. Slides of acid-cleaned material were examined at $400 \times$ to determine relative diatom abundance. Assessment of total diatom abundance was qualitative. Diatoms were recorded as abundant (A) if six or more specimens were present in one field of view at $400 \times$, common $(\mathrm{C})$ if one to five specimens occurred in one field of view, few $(F)$ if one to four specimens occurred in five fields of view, and rare $(\mathrm{R})$ if one to 10 specimens occurred per horizontal traverse.

Qualitative abundance estimates of individual taxa are based on the number of specimens observed per field of view at 400×. Species were recorded as abundant (A) if two or more specimens were present in one field of view, common (C) if one to five specimens were observed per five fields of view, few $(\mathrm{F})$ if two to 10 specimens were observed per horizontal traverse, rare $(\mathrm{R})$ if one specimen was observed per horizontal traverse, and trace $(\mathrm{T})$ if only fragments of the specimen were observed. 
Figure 1. Location of Site 983 plotted with previous DSDP and ODP sites in the area. Areas of sediment drift accumulation are shown by dotted pattern. Position of the Polar Front is indicated by the dotted line.

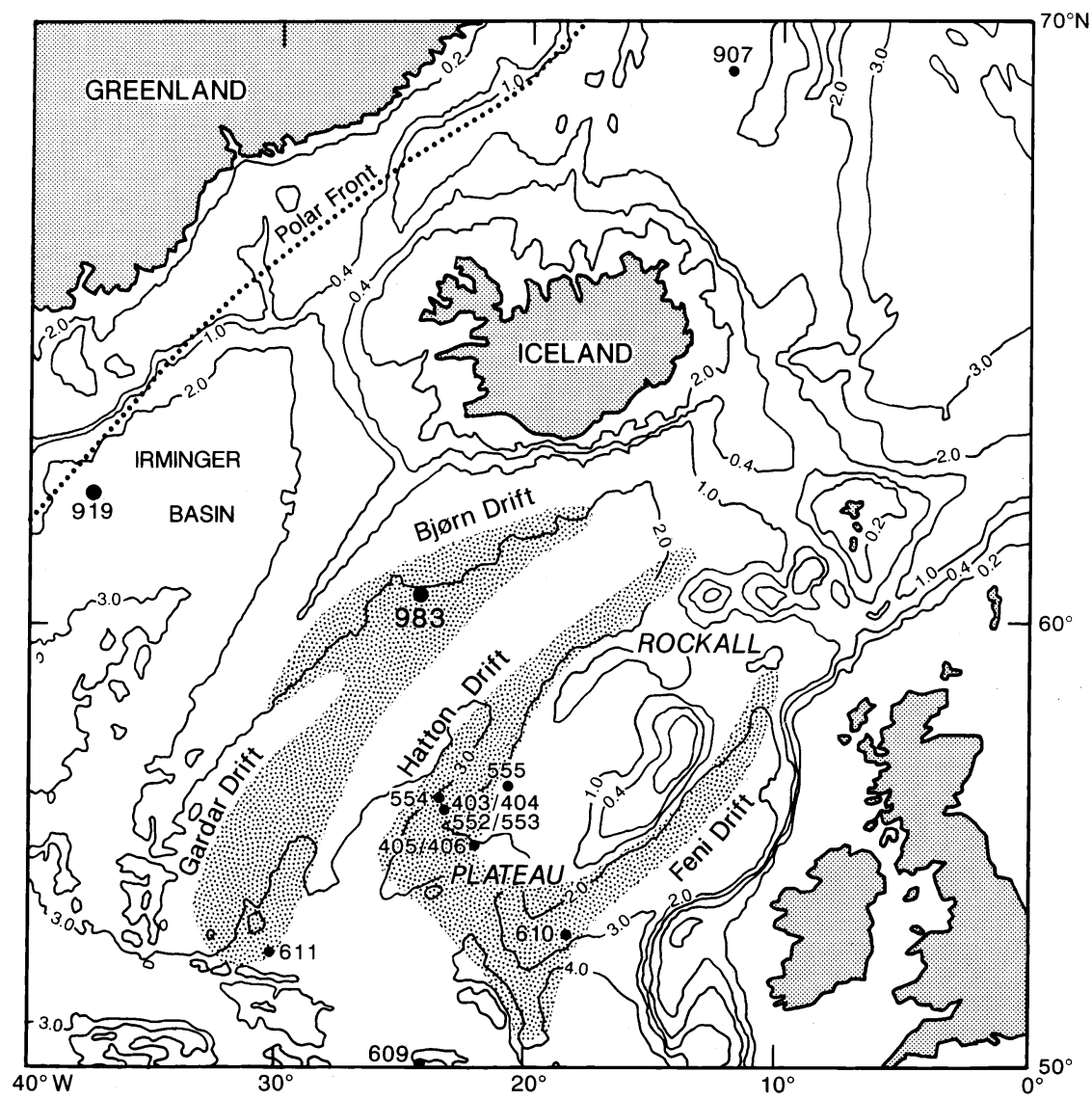

(73.89 mbsf). The LO of $N$. seminae is seen in Sample 162-983A$10 \mathrm{H}-5,49-50 \mathrm{~cm}$ (89.89 mbsf). The FO of $N$. seminae is observed in Sample 162-983A-16H-1, 49-50 cm (140.89 mbsf). The FO of $P$. doliolus occurs in Sample 162-983A-26H-CC, 0-3 cm (244.99 mbsf) as reported in Jansen, Raymo, Blum, et al. (1996). The depth ranges of these events are presented in Table 2.

\section{Diatom Datum Levels}

\section{PLEISTOCENE DIATOM BIOSTRATIGRAPHY}

At present, the area of Site 983 is influenced by subarctic water masses created by the confluence of the polar waters of the ice-laden East Greenland Current with the Atlantic waters of the Irminger Current. The Pleistocene diatom species observed in sediment recovered from Site 983 consist primarily of modern arctic and subarctic species (Koç Karpuz and Schrader, 1990; N. Koç, unpubl. data). These include Actinocyclus curvatulus, Thalassiosira gravida spore and vegetative cells, Rhizosolenia hebetata, Thalassiothrix longissima, and the warm-water species Thalassiosira oestrupii (Table 1).

Diatoms are generally abundant to common and good to moderately preserved in Site 983 sediments (Table 1). Eight biostratigraphic events are observed at Site 983: the last occurrence (LO) and the first occurrence (FO) of Proboscia curvirostris, the LO of Thalassiosira jouseae, the LO of Nitzschia reinholdii, the LO of Nitzschia fossilis, the LO and FO of Neodenticula seminae, and the FO of Pseudoeunotia doliolus (Fig. 2). The LO of P. curvirostris and T. jouseae occurs in Sample 162-983A-4H-3, 49-50 cm (29.89 meters below seafloor [mbsf]). The FO of $P$. curvirostris is observed in Sample $162-983 \mathrm{~A}-20 \mathrm{H}-5,49-50 \mathrm{~cm}$ (184.89 mbsf). The LO of $N$. reinholdii is observed in Sample 162-983A-7H-7, 49-50 cm (64.39 mbsf). The LO of $N$. fossilis is noted in Sample 162-983A-8H-7, 49-50 cm
Age assignments for the biostratigraphic events were achieved by correlation with the magnetostratigraphy (Jansen, Raymo, Blum, et al., 1996) and with the oxygen isotope record of Site 983 (D. Hodell, unpubl. data; H. Kleiven, unpubl. data). Datum levels from youngest to oldest are as follows:

1. The LO of T. jouseae and the LO of P. curvirostris co-occur at the end of Marine Isotope Stage (MIS) 9 (Fig. 3). Interpolation of age using the stage boundaries gives an age between 0.295 and $0.305 \mathrm{Ma}$ for these events (Table 2). At ODP Site 919, both of these events were recorded within MIS 9 with the LO of T. jouseae (referred to as T. nidulus in Koç and Flower, 1998) dated to 0.309 Ma and the LO of $P$. curvirostris to an age of $0.335 \mathrm{Ma}$. In the southern Labrador Sea, at Hole 646A, the LO of P. curvirostris was recorded in Sample 105-646A-3H-1, 128-130 cm (Monjanel and Baldauf, 1989). Correlation of this sample with the oxygen isotope record of Site 646 (Aksu et al., 1989) places the event within MIS 8, giving a slightly younger age than at Sites 919 and 983.

Both of these events are also recorded from the North Pacific. The LO of T. jouseae is dated between 0.280 and $0.390 \mathrm{Ma}$ in the Northwest Pacific, showing a possible diachrony from high to low latitudes (Koizumi and Tanimura, 1985). The North Atlantic ages for the LO of $T$. jouseae from Sites 646, 919, and 983 fall closer to the younger 
Table 1. Diatoms of Hole 983A.

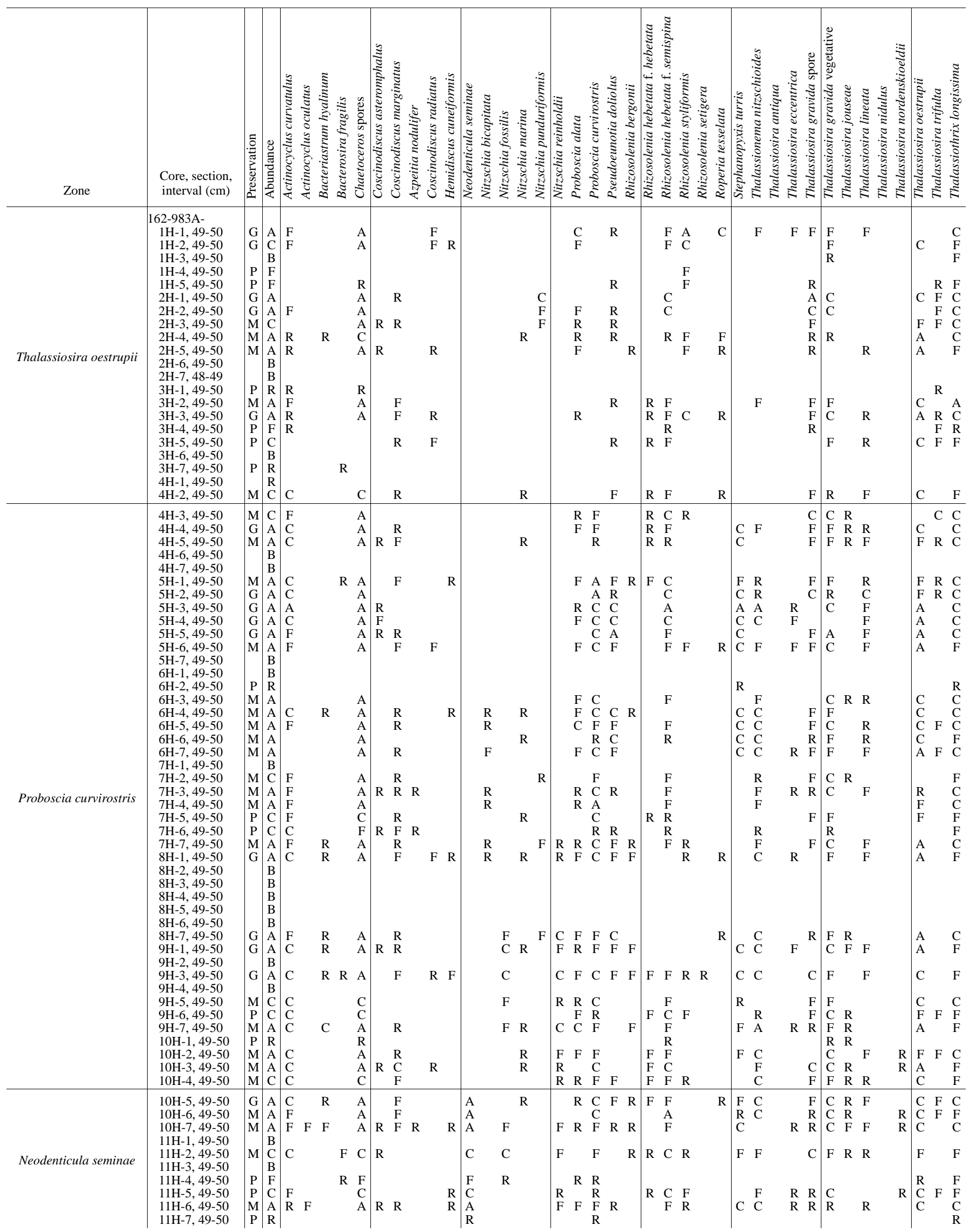


Table 1 (continued).

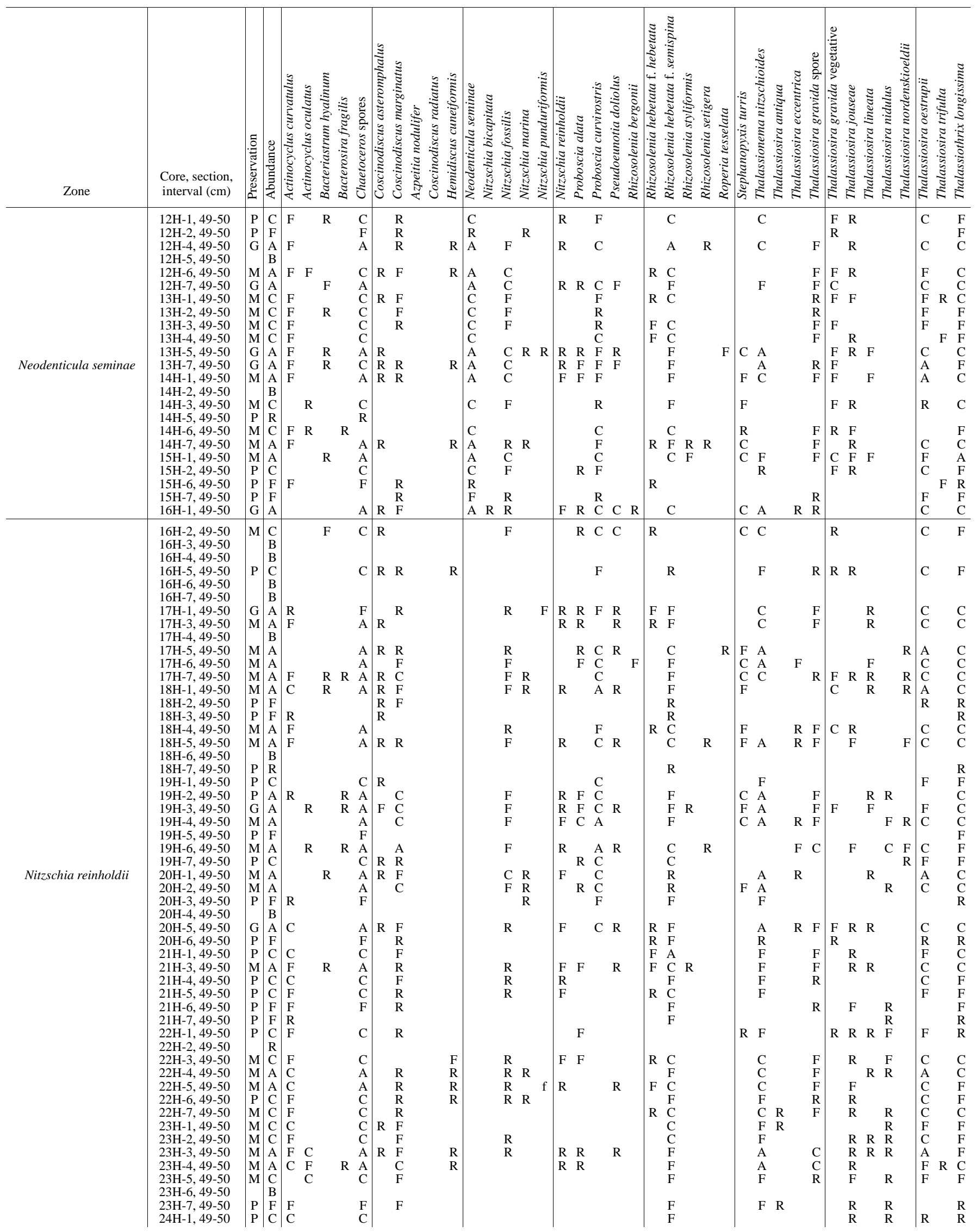


Table 1 (continued).

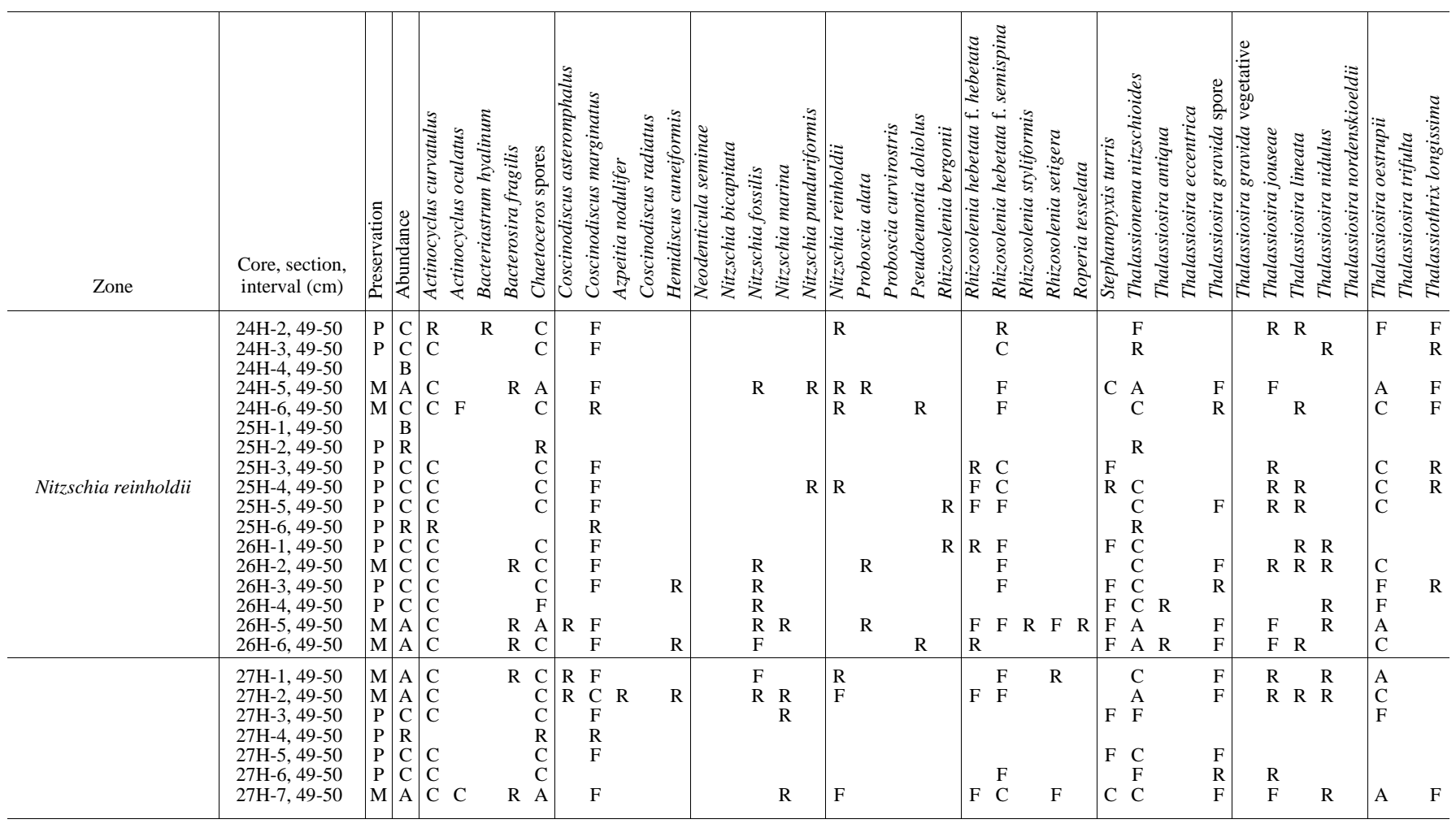

Notes: $\mathrm{B}=$ barren, $\mathrm{T}$ = trace, $\mathrm{R}=$ rare, $\mathrm{F}=$ few, $\mathrm{C}=$ common, $\mathrm{A}=$ abundant. Preservation is either poor $(\mathrm{P})$, moderate $(\mathrm{M})$, or good $(\mathrm{G})$. See Appendix for species list.

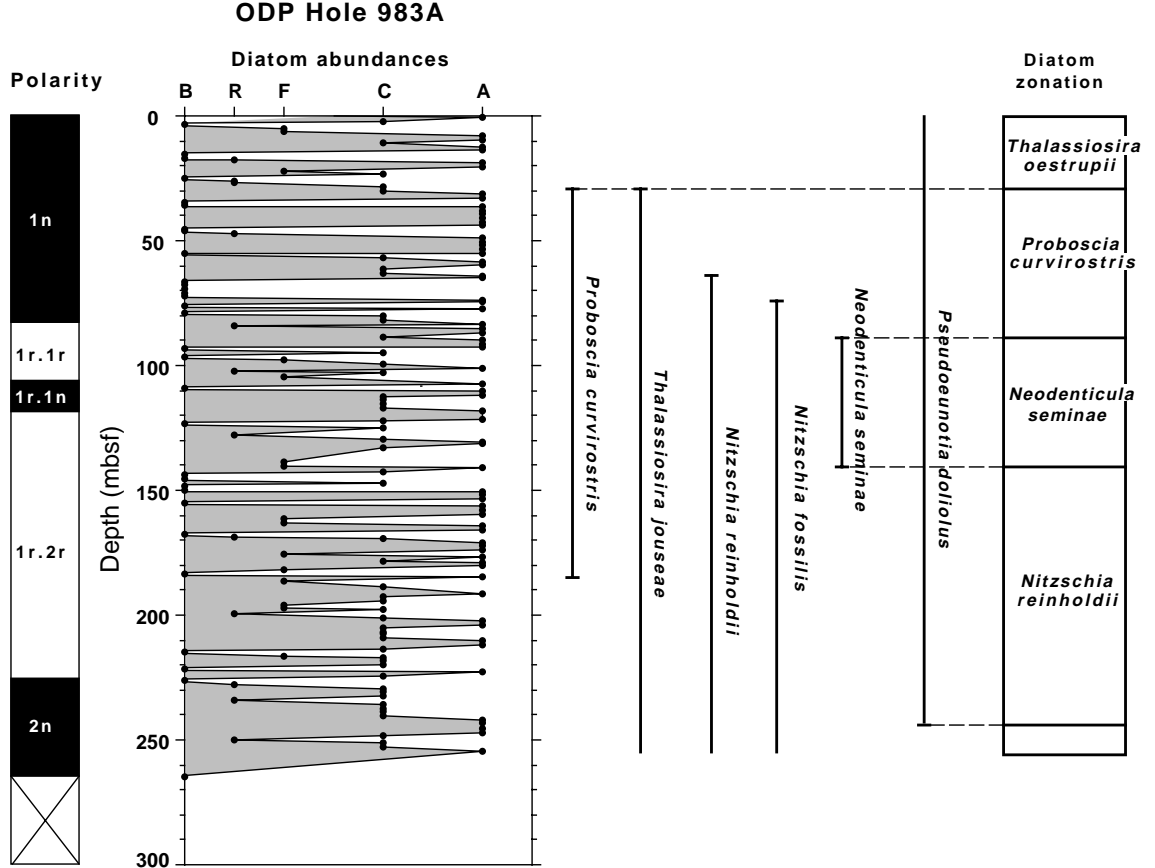

Figure 2. Hole $983 \mathrm{~A}$ relative diatom abundances $(\mathrm{B}=$ barren, $\mathrm{R}=$ rare, $\mathrm{F}$ = few, $\mathrm{C}=$ common, $\mathrm{A}=$ abundant) plotted with the paleomagnetic stratigraphy vs. depth. Also shown are diatom biostratigraphic events and their ranges used to propose the high-latitude North Atlantic diatom zonation. datum from the middle- and high-latitude North Pacific. Thus, it is possible to conclude that this event is synchronous between the middle and high latitudes of both oceans.

The LO of $P$. curvirostris is dated at $0.300-0.350 \mathrm{Ma}$ in the middle- and high-latitude North Pacific (Koizumi and Tanimura, 1985; Koizumi, 1986). The overlap in age observed between the North At- lantic and the North Pacific suggests synchroneity between these two oceans for this event. P. curvirostris is also recorded from Sites 552, 606, 607, 609, and 611 in the North Atlantic (Baldauf, 1984, 1987). It is also recorded from the Nordic Seas Sites 907 (Koç and Scherer, 1996) and 986 (Jansen, Raymo, Blum, et al., 1996), which implies a distribution for $P$. curvirostris that stretches from $40^{\circ} \mathrm{N}$ to $80^{\circ} \mathrm{N}$ in the 
North Atlantic. It also has a middle- to high-latitude distribution in the North Pacific, which makes it a valuable datum for correlation between the high-latitude North Atlantic and the North Pacific Oceans.

2. The LO of $N$. reinholdii is recorded within MIS 15 with an estimated age of 0.590-0.601 Ma (Table 2; Fig. 3). Baldauf (1987) tentatively estimated the age of this event at $0.44 \mathrm{Ma}$ on the basis of DSDP Sites 607 and 609, which had the most refined sample constraints. We correlated the depth interval (Sample 94-609-4-1, 43-45 $\mathrm{cm}, 26.64 \mathrm{mbsf}$ ) of this event with the oxygen isotope curve of Hole 609 (L. Labeyrie, unpubl. data) and found that it plots within MIS 13 (0.46-0.50 Ma) (Fig. 4). We have also correlated the depth interval of this event at Site 607 from Baldauf (1987) with the oxygen isotope record of Site 607 (Ruddiman et al., 1987) and found that it also plots within MIS 13. This suggests that the LO of $N$. reinholdii is diachronous between the middle and high latitudes of the North Atlantic. Furthermore, this species is totally absent from Site 919 sediments

Table 2. Specific diatom events and estimated ages from Hole 983A.

\begin{tabular}{|c|c|c|c|c|}
\hline Diatom event & $\begin{array}{l}\text { Core, section, } \\
\text { interval }(\mathrm{cm})\end{array}$ & $\begin{array}{l}\text { Depth } \\
\text { (mbsf) }\end{array}$ & $\begin{array}{l}\text { Depth } \\
\text { (mcd) }\end{array}$ & $\begin{array}{c}\text { Estimated age } \\
\text { (Ma) }\end{array}$ \\
\hline LO Proboscia curvirostris & $\begin{array}{l}162-983 \mathrm{~A}- \\
4 \mathrm{H}-2,49-50 \\
4 \mathrm{H}-3,49-50\end{array}$ & $\begin{array}{l}28.39 \\
29.89\end{array}$ & $\begin{array}{l}32.35 \\
33.85\end{array}$ & $\begin{array}{l}0.295 \\
0.305\end{array}$ \\
\hline LO Thalassiosira jouseae & $\begin{array}{l}4 \mathrm{H}-2,49-50 \\
4 \mathrm{H}-3,49-50\end{array}$ & $\begin{array}{l}28.39 \\
29.89\end{array}$ & $\begin{array}{l}32.35 \\
33.85\end{array}$ & $\begin{array}{l}0.295 \\
0.305\end{array}$ \\
\hline LO Nitzschia reinholdii & $\begin{array}{l}7 \mathrm{H}-6,49-50 \\
7 \mathrm{H}-7,49-50\end{array}$ & $\begin{array}{l}62.89 \\
64.39\end{array}$ & $\begin{array}{l}70.19 \\
71.69\end{array}$ & $\begin{array}{l}0.590 \\
0.601\end{array}$ \\
\hline LO Nitzschia fossilis & $\begin{array}{l}8 \mathrm{H}-6,49-50 \\
8 \mathrm{H}-7,49-50\end{array}$ & $\begin{array}{l}72.39 \\
73.89\end{array}$ & $\begin{array}{l}80.26 \\
81.76\end{array}$ & $\begin{array}{l}0.675 \\
0.687\end{array}$ \\
\hline LO Neodenticula seminae & $\begin{array}{l}10 \mathrm{H}-4,49-50 \\
10 \mathrm{H}-5,49-50\end{array}$ & $\begin{array}{l}88.39 \\
89.89\end{array}$ & $\begin{array}{l}97.73 \\
99.23\end{array}$ & $\begin{array}{l}0.836 \\
0.849\end{array}$ \\
\hline FO Neodenticula seminae & $\begin{array}{l}16 \mathrm{H}-1,49-50 \\
16 \mathrm{H}-2,49-50\end{array}$ & $\begin{array}{l}140.89 \\
142.39\end{array}$ & $\begin{array}{l}154.79 \\
156.29\end{array}$ & $\begin{array}{l}1.250 \\
1.260\end{array}$ \\
\hline FO Proboscia curvirostris & $\begin{array}{l}20 \mathrm{H}-5,49-50 \\
20 \mathrm{H}-6,49-50\end{array}$ & $\begin{array}{l}184.89 \\
186.39\end{array}$ & $\begin{array}{l}202.32 \\
203.82\end{array}$ & $\begin{array}{l}1.521 \\
1.530\end{array}$ \\
\hline FO Pseudoeunotia doliolus & $\begin{array}{l}26 \mathrm{H}-\mathrm{CC}, 0-3 \\
27 \mathrm{H}-1,49-50\end{array}$ & $\begin{array}{l}244.99 \\
245.39\end{array}$ & $\begin{array}{l}269.03 \\
270.08\end{array}$ & $\begin{array}{l}1.891 \\
1.893\end{array}$ \\
\hline
\end{tabular}

Note: $\mathrm{LO}=$ last occurrence, $\mathrm{FO}=$ first occurrence.
(Koç and Flower, 1998). Koizumi and Tanimura (1985) found that the LO of $N$. reinholdii is almost synchronous at $0.47-0.52 \mathrm{Ma}$ in middle and high latitudes of the North Pacific. This datum correlates well with the Hole 609 datum indicating the synchroneity of this event between the middle latitudes of both oceans.

3. The LO of $N$. fossilis occurs at the end of MIS 17 and has an estimated age of 0.675-0.687 Ma (Fig. 3). Baldauf (1987) estimated an age of $0.58-0.60 \mathrm{Ma}$ for this event in the middle-latitude North Atlantic, indicating that this event is also diachronous between the middle and high latitudes of the North Atlantic. Koizumi and Tanimura (1985) found this event to be synchronous at $0.55 \mathrm{Ma}$ in middle and high latitudes of the North Pacific, which suggests a near synchroneity between the middle and high latitudes of the North Pacific and the middle latitudes of the North Atlantic for the LO of $N$. fossilis.

4. The LO of $N$. seminae occurs within MIS 21 and has an estimated age of 0.836-0.849 Ma (Fig. 3). At Site 919, this event occurs within MIS 22 (Koç and Flower, 1998). However, because there is a barren interval above this event encompassing MIS 21, the age is interpolated to be between 0.817 and $0.895 \mathrm{Ma}$.

$N$. seminae belongs to the modern assemblage of the middle- and high-latitude North Pacific (Barron, 1981; Sancetta and Silvestri, 1986). However, it became extinct in the North Atlantic during the late Quaternary (Baldauf, 1986). Baldauf (1986) found the LO of $N$. seminae to be diachronous between Site 607 ( 0.8 Ma) and Sites 609 and 611 ( 0.7 Ma). We correlated the depth interval of this event at Site 607 from Baldauf (1987) with the oxygen isotope record of Site 607 (Ruddiman et al., 1987) and found that it plots within MIS 21. On Figure 4, we plotted the depth range of this event together with the oxygen isotope record of Site 609 and compared it with the record of Site 983 . The event plots within MIS 21 in both sites, indicating a synchroneity between the middle and high latitudes of the North Atlantic.

Montane and Baldauf (1989) recorded the LO of $N$. seminae at Site 646 from the southern Labrador Sea in Sample 105-646A-7H-5, $120-122 \mathrm{~cm}$. We correlated this sample with the oxygen isotope record of Hole 646A (Aksu et al., 1989). It plots near the midpoint of MIS 21, thereby correlating well with other North Atlantic datums for this event. We conclude that the LO of $N$. seminae, which occurs

\section{ODP Site 983}

Figure 3. Site 983 relative diatom abundances $(B=$ barren, $\mathrm{R}=$ rare, $\mathrm{F}=$ few, $\mathrm{C}=$ common, $\mathrm{A}=$ abundant) plotted with the planktonic $\delta^{18} \mathrm{O}$ record vs. composite depth. Interglacial stages are shaded and numbered. Diatom biostratigraphic events and their ranges are indicated and correlated with the $\delta^{18} \mathrm{O}$ record.

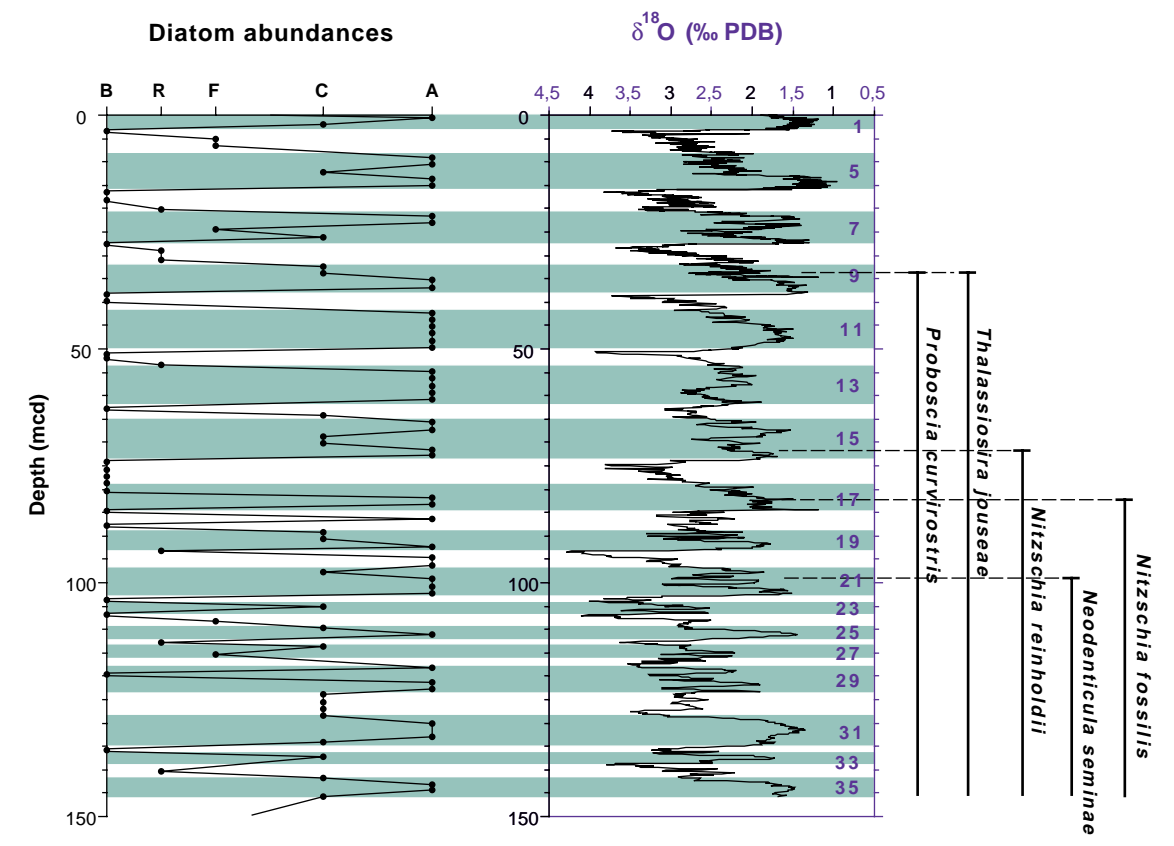


DSDP Site 609

Polarity

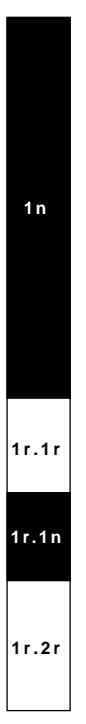

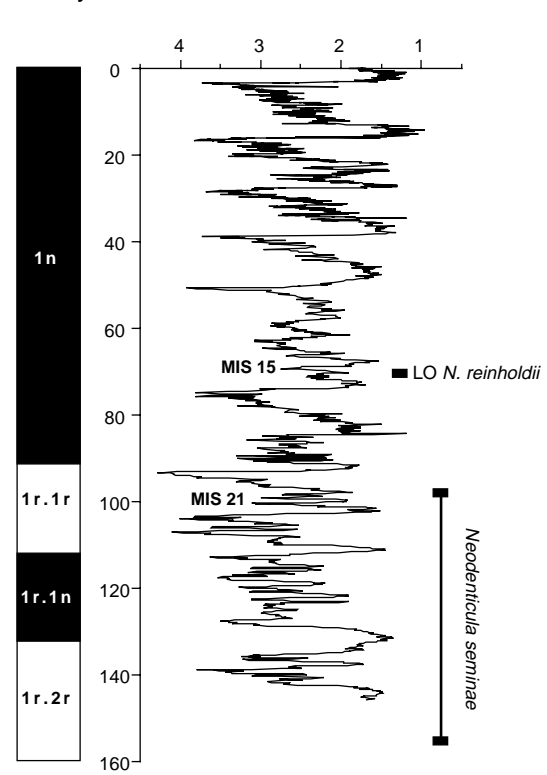

ODP Site 983

Figure 4. Planktonic $\delta^{18} \mathrm{O}$ records of Site 609 (L. Labeyrie, unpubl. data) and Site 983 (D. Hodell and H. Kleiven, unpubl. data) shown with their respective paleomagnetic stratigraphies. To compare the timing of events between the middle- and high-latitude North Atlantic, we plotted the last occurrence (LO) of Nitzschia reinholdii, and the last and first occurrences of Neodenticula seminae at both sites. MIS = marine isotope stage. within MIS 21, is synchronous within the middle and high latitudes of the North Atlantic.

5. The FO of $N$. seminae occurs between 154.79 and 156.29 meters composite depth, which falls toward the end of MIS 37 (M. Raymo, pers. comm., 1998) and has an estimated age of 1.250-1.260 Ma. Baldauf (1987) recorded the FO of $N$. seminae one-fifth of the way between the base of the Jaramillo Subchron and the top of the Gauss paleomagnetic Chron in Holes 607, 609, and 611 and concluded that it is isochronous throughout Leg 94 material. We plotted the depth interval of the FO of $N$. seminae on Site 609 isotope curve and found that it occurs within the interval of MISs 37-35 (Fig. 4). We conclude that the FO of $N$. seminae is also synchronous between the middle and high latitudes of the North Atlantic. The North Pacific datum for this event is uncertain because of previous taxonomic ambiguities between $N$. seminae, $N$. koizumii, and $N$. sp. A (Akiba and Yanagisawa, 1986).

6. The FO of P. curvirostris has an estimated age of 1.521-1.530 Ma at Site 983. In the North Pacific, this event seems to be diachronous, migrating from the subarctic North Pacific where it occurred midway between the Olduvai and Jaramillo events. This gave an estimated age of 1.4 Ma to transitional waters at $1.1 \mathrm{Ma}$ and to the subtropics at $0.95 \mathrm{Ma}$ (Koizumi, 1986). A similar diachroneity seems probable also for the North Atlantic based on results from Sites 609 and 611 (Baldauf, 1987).

7. The FO of $P$. doliolus occurs within the Olduvai event and has an estimated age of 1.891-1.893 Ma. Baldauf (1987) assigned an age of $1.84 \mathrm{Ma}$ to this event in the North Atlantic. In the North Pacific, Koizumi and Tanimura (1985) assigned a first-order category to the FO of $P$. doliolus with an approximate age of 1.9 Ma in middle latitudes. These results point to a synchronous first occurrence for $P$. doliolus in the middle and high latitudes of both the North Atlantic and the North Pacific Oceans.

\section{Zonation}

The diatom zones for the North Atlantic are defined by warmtemperate species (Baldauf, 1984, 1987). However, because of the latitudinal dependence of diatom distribution after the Miocene, it is necessary to make up at least two kinds of zonal schemes: one for low latitudes and another for high latitudes (Burckle and Opdyke, 1977).
Schrader and Fenner (1976) and Dzinoridze et al. (1978) proposed two different Neogene diatom biostratigraphies for the Nordic Seas on the basis of Leg 38 material. Recently, Koç and Scherer (1996) proposed a new Neogene diatom zonation for the area on the basis of Site 907 material. In all cases, however, the Pleistocene zonation did not have much resolution because of the absence of diatoms in the investigated sediments. Site 919, drilled during Leg 152, provided us with a high-accumulation-rate upper Pleistocene section with abundant diatoms, which enabled us for the first time both to record arcticsubarctic diatom events and to tie them directly to the oxygen isotope record (Koç and Flower, 1998). On the basis of these results, a late Pleistocene zonation for the high-latitude North Atlantic was proposed (Koç and Flower, 1998).

A Pleistocene diatom zonation scheme is proposed for the highlatitude North Atlantic (Figs. 2, 5). Zonal boundaries are judged to be first order because the datum levels that define them are tied either directly to oxygen isotope stages or to the paleomagnetic reversal record. Furthermore, these datums are synchronous between the middle and high latitudes of the North Atlantic and the North Pacific, making correlations between the two oceans possible.

\section{Thalassiosira oestrupii Zone}

Authors: Koç and Scherer (1996)

Definition: The interval from the LO of Proboscia curvirostris to the present.

Remarks: Proboscia curvirostris is a highly silicified species with wide geographic distribution. The LO of $P$. curvirostris is synchronous between the middle and high latitudes of both the North Atlantic and the North Pacific Oceans, making it a very valuable datum. The LO of $T$. jousea occurs at the same time as the LO of $P$. curvirostris, but because of its sparse occurrence in sediments, it can only be used as a secondary datum.

Correlation: This zone correlates with the Neodenticula seminae (NPD12) Zone (Donahue, 1970) of the North Pacific, which also uses the LO of $P$. curvirostris to define its base (Fig. 5).

Age: Quaternary, 0.3-0 Ma.

\section{Proboscia curvirostris Zone}

Author: Koç (Koç and Flower, 1998).

Definition: The top of the zone is defined by the LO of $P$. curvirostris and the base by the LO of Neodenticula seminae. 


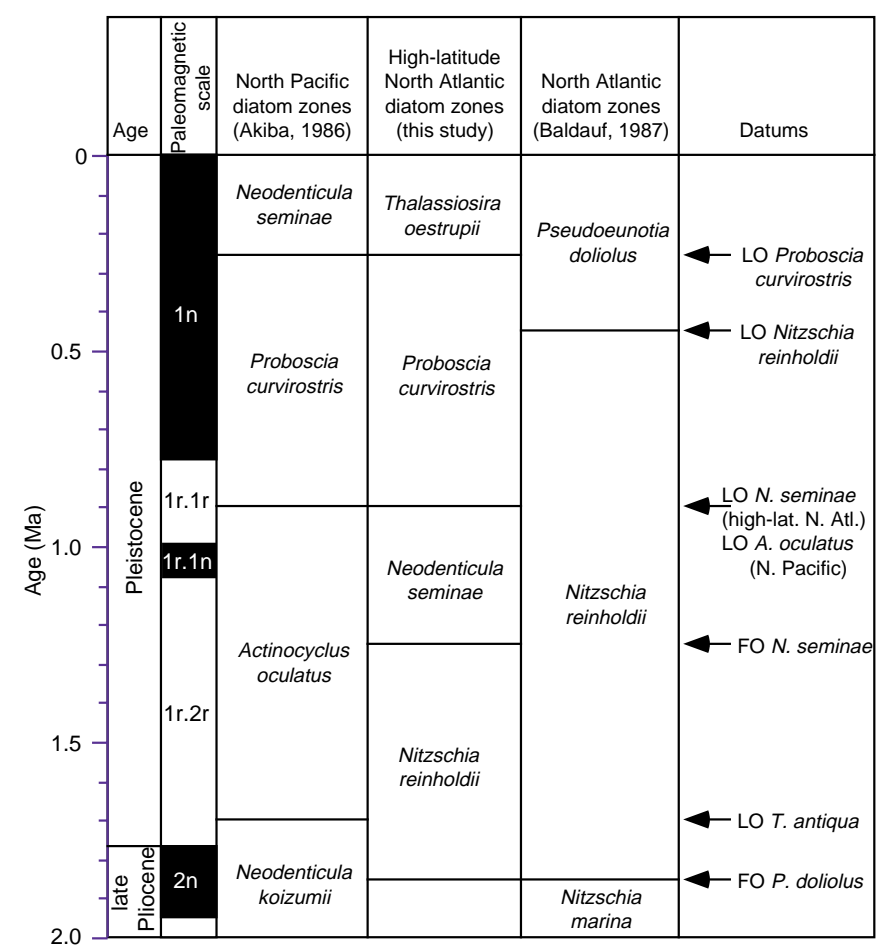

Figure 5. Correlation of various Pleistocene diatom zones and the first-order datums. $\mathrm{LO}=$ last occurrence.

Remarks: The base of this zone is modified from its original description by Koç and Scherer (1996) as the interval from the LO of Thalassiothrix miocenica to the LO of P. curvirostris, which included an extended, mostly barren section at its original site of description (Site 907).

The LO of $N$. reinholdii and $N$. fossilis falls within this zone (Fig. 2). Baldauf (1987) used the LO of $N$. reinholdii datum to separate his $P$. doliolus Zone from the $N$. reinholdii Zone. These species (especially $N$. reinholdii) have sparse and sporadic occurrences in Site 983 sediments and are absent from Site 919 sediments. Therefore, they cannot be used to define zones in the high-latitude North Atlantic.

Correlation: This zone correlates with the Rhizosolenia curvirostris (synonym for Proboscia curvirostris) Zone of the North Pacific (Donahue, 1970) (Fig. 5).

Age: Quaternary, $0.836-0.849$ to $0.3 \mathrm{Ma}$.

\section{Neodenticula seminae Zone}

Author: Koç (this study).

Definition: The top of the zone is defined by the LO of $N$. seminae and the base by the $\mathrm{FO}$ of $N$. seminae.

Remarks: This zone is modified from Koç and Flower (1998) where the base of the zone was not reached at Site 919 . The FO and LO of N. seminae are synchronous within the middle and high latitudes of the North Atlantic.

The LO of Actinocyclus oculatus is also recorded at the same level as the LO of N. seminae in Site 983 sediments, but because of its sporadic occurrence it is not used to define a zone (Table 1). The LO of A. oculatus seems to be synchronous in the North Pacific and at Site 983.

Correlation: This zone correlates with the top part of the Actinocyclus oculatus Zone of the North Pacific diatom zones (Koizumi, 1973).

Age: Quaternary, $1.25-1.26$ to $0.84-0.85 \mathrm{Ma}$.

\section{Nitzschia reinholdii Zone}

Author: Koç (this study)

Definition: The top of the zone is defined by the FO of $N$. seminae and the base by the FO of P. doliolus.

Remarks: This zone is modified from its definition by Baldauf (1987).

The LO of T. antiqua is recorded within the bottom half of the zone (Sample 162-983A-22H-7, 49-50 cm, $206.89 \mathrm{mbsf}$ ) with an estimated age of 1.65
Ma. This event defines the base of the North Pacific A. oculatus Zone and is given an age of 1.7 Ma (Donahue, 1970).

Correlation: This zone correlates with the bottom part of the North Atlantic $N$. reinholdii Zone of Baldauf (1987).

Age: early Pleistocene to latest Pliocene, 1.89 to $1.25-1.26$ Ma.

\section{DIATOM ABUNDANCES: PALEOCEANOGRAPHIC IMPLICATIONS}

Site 983 lies just south of Iceland at $60^{\circ} \mathrm{N}$ (Fig. 1). Diatom abundance and preservation at this site fluctuate in response to changing oceanographic conditions affecting diatom productivity. Correlating diatom abundance variations with the oxygen isotope record of Site 983 reveals a great similarity between the two records (Fig. 3). In general, interglacials are related to high diatom productivity (common to abundant diatoms), whereas glacial stages are often barren of diatoms. However, diatom production was significant during glacial Stages 18, 20, and 30 .

During the late Quaternary glacial periods, oceanic polar fronts and sea ice migrated equatorward, with some of the most dramatic changes occurring in the North Atlantic (McIntyre, et al., 1976; CLIMAP Project Members, 1981). Reduced surface-water productivity during glacials indicates that these were the intervals during which the Polar Front migrated southeastward, thereby covering Site 983 with sea ice. Considering the proximity of the sea-ice margin to the area at present, it is very probable that these diatom-barren glacial intervals reflect periods when the site was under heavy sea-ice cover.

Presence of significant diatom production during glacial stages 18, 20, and 30 indicates open-marine conditions over Site 983 during these times. High diatom production during glacial stages 18 and 20 is also recorded from Site 919, which suggests that the North Atlantic was free of sea ice during these glacial periods (Koç and Flower, 1998). These glacial stages are within the first 100-k.y. cycles after the Mid-Pleistocene Transition. As indicated by the benthic oxygen isotope records, they were not as severe as the late Quaternary glacials (Mix et al., 1995).

Neodenticula seminae is part of the modern diatom assemblage of the middle- and high-latitude North Pacific (Barron, 1981; Sancetta, 1982). Our results indicate that this species is limited to the interval 0.84-1.26 Ma in the North Atlantic. Baldauf (1986) had interpreted the occurrence of $N$. seminae in the North Atlantic as the presence of cool, low-saline, surface waters in the central North Atlantic during the early Quaternary. The interval of $N$. seminae in the North Atlantic straddles the transition from the dominance of 41-k.y. cycles in the climate records to the dominance of 100-k.y. cycles. It is, therefore, possible to interpret the first occurrence of $N$. seminae in the North Atlantic as a sign for cooling, which started at $1.26 \mathrm{Ma}$, leading to the establishment of the 100-k.y. cycles with severe glacial periods. The presence of $N$. seminae in the North Atlantic is, therefore, attributable to the unique conditions related to the Mid-Pleistocene Transition.

\section{CONCLUSIONS}

Diatom investigations of Site 983 refined and increased the Pleistocene diatom biostratigraphic resolution of the high-latitude North Atlantic. Eight Pleistocene diatom datum events are identified and tied directly to the oxygen isotope record and paleomagnetic stratigraphy of Site 983 . These datum events are (1) the LO of P. curvirostris at $0.3 \mathrm{Ma}$, (2) the LO of T. jouseae at $0.3 \mathrm{Ma}$, (3) the LO of $N$. reinholdii at $0.6 \mathrm{Ma}$, (4) the $\mathrm{LO}$ of $N$. fossilis at $0.68 \mathrm{Ma}$, (5) the LO of $N$. seminae at $0.84 \mathrm{Ma},(6)$ the $\mathrm{FO}$ of $N$. seminae at $1.25 \mathrm{Ma},(7)$ the FO of $P$. curvirostris at $1.53 \mathrm{Ma}$, and (8) the $\mathrm{FO}$ of $P$. doliolus at $1.89 \mathrm{Ma}$. On the basis of these datums, four high-latitude North Atlantic diatom zones are proposed for the Pleistocene. 
The record of diatom abundance and preservation at Site 983 gives evidence for the influence of fluctuating Pleistocene climatic conditions on diatom productivity in the high-latitude North Atlantic.

\section{ACKNOWLEDGMENTS}

We thank Eystein Jansen and Maureen Raymo for the opportunity to participate in Leg 162 scientific work. We thank John Barron and Lloyd Burckle for providing constructive reviews, O. Tumyr for his assistance with the scanning electron microscope pictures, and J. Ellingsen for the preparation of the plates. M. Raymo provided the DSDP Site 609 samples for the isotope analyses, H. Leclerc prepared the samples, and the French CEA and CNRS supported the work. This study is supported by grants from the Norwegian Research Foundation and the Norwegian Petroleum Directory to N. Koç.

\section{REFERENCES}

Akiba, F., 1986. Middle Miocene to Quaternary diatom biostratigraphy in the Nankai trough and Japan trench, and modified lower Miocene through Quaternary diatom zones for middle-to-high latitudes of the North Pacific. In Kagami, H., Karig, D.E., Coulbourn, W.T., et al., Init. Repts. DSDP, 87: Washington (U.S. Govt. Printing Office), 393-481.

Akiba, F., and Yanagisawa, Y., 1986. Taxonomy, morphology and phylogeny of the Neogene diatom zonal marker species in the middle-to-high latitudes of the North Pacific. In Kagami, H., Karig, D.E., Coulbourn, W.T., et al., Init. Repts. DSDP, 87: Washington (U.S. Govt. Printing Office), 483-554.

Aksu, A.E., de Vernal, A., and Mudie, P.J., 1989. High-resolution foraminifer, palynologic, and stable isotopic records of upper Pleistocene sediments from the Labrador Sea: paleoclimatic and paleoceanographic trends. In Srivastava, S.P., Arthur, M.A., Clement, B., et al., Proc. ODP, Sci. Results, 105: College Station, TX (Ocean Drilling Program), 617652.

Baldauf, J.G., 1984. Cenozoic diatom biostratigraphy and paleoceanography of the Rockall Plateau region, North Atlantic, Deep Sea Drilling Project Leg 81. In Roberts, D.G., Schnitker, D., et al., Init. Repts. DSDP, 81: Washington (U.S. Govt. Printing Office), 439-478.

Baldauf, J.G., 1986. Diatom biostratigraphic and paleoceanographic interpretations for the middle and high latitude North Atlantic Ocean. In Summerhayes, C.P., and Shackleton, N.J. (Eds.), North Atlantic Paleoceanography. Geol. Soc. Spec. Publ. London, 21:243-252.

Baldauf, J.G., 1987. Diatom biostratigraphy of the middle- and high-latitude North Atlantic Ocean, Deep Sea Drilling Project Leg 94. In Ruddiman, W.F., Kidd, R.B., Thomas, E., et al., Init. Repts. DSDP, 94 (Pt. 2): Washington (U.S. Govt. Printing Office), 729-762.

Barron, J.A., 1981. Late Cenozoic diatom biostratigraphy and paleoceanography of the middle-latitude eastern North Pacific, Deep Sea Drilling Project Leg 63. In Yeats, R.S., Haq, B.U., et al., Init. Repts. DSDP, 63: Washington (U.S. Govt. Printing Office), 507-538.

Brightwell, T., 1858. Remarks on the genus "Rhizosolenia" of Ehrenberg. $Q$. J. Microsc. Sci., 6:93-95.

Burckle, L.H., and Opdyke, N.D., 1977. Late Neogene diatom correlations in the Circum-Pacific. In Ujiié, H., and Saito, T. (Eds.), Proc. 1st Int. Congr. Pac. Neogene Stratigr.: Tokyo (Kaiyo Shupan), 255-284.

Cleve, P.T., 1873. Examination of diatoms found on the surface of the Sea of Java. Bih. Sven. Vetensk.-Akad. Handl., 11:113.

CLIMAP Project Members, 1981. Seasonal reconstructions of the Earth's surface at the last glacial maximum. Geol. Soc. Am., Map and Chart Ser., MC36.

Donahue, J.G., 1970. Pleistocene diatoms as climatic indicators in North Pacific sediments. In Hays, J.D. (Ed.), Geological Investigations of the North Pacific. Mem.-Geol. Soc. Am., 126:121-138.

Dzinoridze, R.N., Jousé, A.P., Koroleva-Golikova, G.S., Kozlova, G.E., Nagaeva, G.S., Petrushevskaya, M.G., and Strelnikova, N.I., 1978. Diatom and radiolarian Cenozoic stratigraphy, Norwegian Basin; DSDP Leg 38. In Talwani, M., Udintsev, G., et al., Init. Repts. DSDP, 38, 39, 40, 41 (Suppl.): Washington (U.S. Govt. Printing Office), 289-427.

Ehrenberg, C.G., 1839. Über noch jetz zahlreich lebende Tierarten der Kreidebildung und den Organismus der Polythalamien. Abh. K. Akad. Wiss. Berlin, 81-174.
, 1841. Uber Verbreitung und Einfluss des mikroskopischen Lebens in Süd- und Nordamerika. Abh. K. Akad. Berlin, 139-144.

Fryxell, G.A., and Hasle, G.R., 1972. Thalassiosira eccentrica (Ehrenberg) Cleve, T. symmetrica sp. nov., and some related Centric diatoms. J. Phycol., 8:297-317.

, 1979. The genus Thalassiosira: T.trifuta sp. nova and other species with tricolumnar supports on strutted processes. Nova Hedwigia Beih., 64:13-31.

Fryxell, G.A., Sims, P.A., and Watkins, T.P., 1986. Azpeitia (Bacillariophyceae): related genera and promorphology. Syst. Bot. Monogr., 13:174.

Gran, H.H., 1900. Bemerkungen über einige Planktondiatomeen. Nyt. Mag. Naturv. (Kristiania), 38:103-126.

, 1904. Die Diatomeen der Arktischen Meere, I. Teil: Die Diatomeen des Planktons. Fauna Arct., 3:509-554.

Gregory, W., 1857. On new forms of marine Diatomaceae found in the Firth of Clyde and in Loch Fyne, illustrated by numerous figures drawn by R.K. Greville. Trans. R. Soc. Edinburgh, 21:473-542.

Hasle, G.R., 1960. Phytoplankton and ciliate species from the tropical Pacific. Skr. Nor. Vidensk.—Akad. Kl.1: Mat.—Naturvedensk. Kl., 2:150 .

Hasle, G.R., and Fryxell, G.A., 1977. The genus Thalassiosira: some species with a linear areola array. Nova Hedwigia Beih., 54:15-66.

Hasle, G.R., and Semina, H.J., 1987. The marine planktonic diatoms Thalassiothrix longissima and Thalassiothrix antarctica with comments on Thalassionema spp. and Synedra reinboldii. Diatom Res., 2:175-192.

Hustedt, F., 1927-1966. Die Kieselalgen Deutschlands, Osterreichs und der Schweiz, mit Berücksichtigung der übrigen Länder Europas sowie der angrenzenden Meeresgebiete. In Rabenhorst, L. (Ed.), KryptogamenFlora von Deutschland. Oesterreich und der Schweiz: Leipzig (Akademische Verlagsgesellschaft), Teil I, Sect. 1-4, pp. 1-920, 1927-1930; Teil II, Sect. 1-5, pp. 1-845, 1931-1959; Teil III, Sect. 1-3, pp. 1-816, 1961-1966.

Jansen, E., Raymo, M.E., Blum, P., et al., 1996. Proc. ODP, Init. Repts., 162: College Station, TX (Ocean Drilling Program).

Jordan, R.W., and Priddle, J., 1991. Fossil members of the diatom genus Proboscia. Diatom Res., 6:55-61.

Jousé, A.P., 1961. Diatoms and their roles in indicating the history of oceans. Akad. Nauk. SSSR, Izv. Ser. Geogr., 2:13-20.

Jousé, A.P., 1962. Stratigraphic and paleogeographic investigations in the northwest part of the Pacific ocean. Akad. Nauk SSR Oceanol. Inst., Moscow (in Russian).

Jousé, A.P., 1968. New species of diatoms in bottom sediments of the Pacific and the Sea of Okhotsk. Nov. Systemat. Plant. Non. Vascular., Acad. Nauk S.S.S.R., 3:12-21.

Koç Karpuz, N., and Schrader, H., 1990. Surface sediment diatom distribution and Holocene paleotemperature variations in the Greenland, Iceland and Norwegian Sea. Paleoceanography, 5:557-580.

Koç, N., and Scherer, R.P., 1996. Neogene diatom biostratigraphy of the Iceland Sea Site 907. In Thiede, J., Myhre, A.M., Firth, J.V., Johnson, G.L., and Ruddiman, W.F. (Eds.), Proc. ODP, Sci. Results, 151: College Station, TX (Ocean Drilling Program), 61-74

Koç, N., and Flower, B.P., 1998. High-resolution Pleistocene diatom biostratigraphy and paleoceanography of Site 919 from the Irminger Basin. In Saunders, A.D., Larsen, H.C., and Wise, S.W., Jr. (Eds.), Proc. ODP, Sci. Results, 152: College Station, TX (Ocean Drilling Program), 209219.

Koizumi, I., 1973. The late Cenozoic diatoms of Sites 183-193, Leg 19 Deep Sea Drilling Project. In Creager, J.S., Scholl, D.W., et al., Init. Repts. DSDP, 19: Washington (U.S. Govt. Printing Office), 805-855.

Koizumi, I., 1986. Pliocene and Pleistocene diatom datum levels related with paleoceanography in the Northwest Pacific. Mar. Micropaleontol., 10:309-325.

Koizumi, I., and Tanimura, Y., 1985. Neogene diatom biostratigraphy of the middle latitude western North Pacific, Deep Sea Drilling Project Leg 86. In Heath, G.R., Burckle, L.H., et al., Init. Repts. DSDP, 86: Washington (U.S. Govt. Printing Office), 269-300.

Lauder, H.S., 1864. On new diatoms. Trans. Microsc. Soc. London., 12:6-8.

McIntyre, A., Kipp, N.G., Bé, A.W.H., Crowley, T., Kellogg, T., Gardner, J.V., Prell, W., and Ruddiman, W.F., 1976. The glacial North Atlantic 18,000 years ago: a CLIMAP reconstruction. In Cline, R.M., and Hays, J.D. (Eds.), Investigation of Late Quaternary Paleoceanography and Paleoclimatology. Mem. Geol. Soc. Am., 145:43-76. 
Mix, A.C., Le, J. and Shackleton, N.J., 1995. Benthic foraminiferal stable isotope stratigraphy of Site 846: 0-1.8 Ma. In Pisias, N.G., Mayer, L.A., Janecek, T.R., Palmer-Julson, A., and van Andel, T.H. (Eds.), Proc. ODP, Sci. Results, 138: College Station, TX (Ocean Drilling Program), 839854

Monjanel, A.-L., and Baldauf, J.G., 1989. Miocene to Holocene diatom biostratigraphy from Baffin Bay and Labrador Sea, Ocean Drilling Program Sites 645-646. In Srivastava, S.P., Arthur, M.A., Clement, B., et al., Proc. ODP, Sci. Results, 105: College Station, TX (Ocean Drilling Program), 305-322.

Pritchard, A., 1861. A History of the Infusoria (4th ed.): London (Whittaker and Co.).

Proshkina-Lavrenko, A.I., 1949. Diatomovyi Analis. Bot. Inst. Akad. Nauk USSR, 2:210-224.

Ruddiman, W.F., McIntyre, A., and Raymo, M., 1987. Paleo-environmental results from North Atlantic Sites 607 and 609. In Ruddiman, W.F., Kidd, R.B., Thomas, E., et al., Init. Repts. DSDP, 94 (Pt. 2): Washington (U.S. Govt. Printing Office), 855-878.

Sancetta, C., 1982. Distribution of diatom species in surface sediments of the Bering and Okhotsk Seas. Micropaleontology, 28:221-257.

Sancetta, C., and Silvestri, S., 1986. Pliocene-Pleistocene evolution of the North Pacific ocean-atmosphere system, interpreted from fossil diatoms. Paleoceanography, 1:163-180.

Scherer, R.P., and Koç, N., 1996. Late Paleogene diatom biostratigraphy and paleoenvironments of the northern Norwegian-Greenland Sea. In Thiede, J., Myhre, A.M., Firth, J.V., Johnson, G.L., and Ruddiman, W.F. (Eds.), Proc. ODP, Sci. Results, 151: College Station, TX (Ocean Drilling Program), 75-99.

Schmidt, A., Schmidt, M., Fricke, F., Heiden, H., Müller, O., and Hustedt, F., 1874-1959. Atlas der Diatomaceen-Kunde: Leipzig (O.R. Reisland).

Schrader, H.-J., and Fenner, J., 1976. Norwegian Sea Cenozoic diatom biostratigraphy and taxonomy. In Talwani, M., Udintsev, G., et al., Init. Repts. DSDP, 38: Washington (U.S. Govt. Printing Office), 921-1099.

Simonsen, R., 1979. The diatom system: ideas on phylogeny. Bacillaria, 2:9-71.

Simonsen, R., and Kanaya, T., 1961. Notes on the marine species of the diatom genus Denticula Kütz. Int. Rev. Gesamten Hydrobiol., 46:498-513.

Stabell, B., and Koç, N., 1996. Recent to middle Miocene diatom productivity at Site 907, Iceland Plateau. In Thiede, J., Myhre, A.M., Firth, J.V., Johnson, G.L., and Ruddiman, W.F. (Eds.), Proc. ODP, Sci. Results, 151: College Station, TX (Ocean Drilling Program), 483-492.

Sundström, B.G., 1986. The marine diatom genus Rhizosolenia: a new approach to the taxonomy [Ph.D. dissert.]. Lund Univ, Sweden.

Van Heurck, H., 1880-1885. Synopsis des Diatomées de Belgique: Antwerp (privately published).

Wallich, G.C., 1860. On the siliceous organisms found in the digestive cavities of the Salpae, and their relation to the flint nodules of the Chalk Formation. Trans. Microsc. Soc. London, New Ser. 8:36-55.

\section{Date of initial receipt: 8 September 1997 \\ Date of acceptance: 11 June 1998 \\ Ms 162SR-035}

\section{APPENDIX}

\section{List of Flora}

Actinocyclus curvatulus Janisch, 1878, in Schmidt et al. (1874-1959), pl. 57, fig. 31; Hustedt, 1958, pp. 129-130, pl. 8, fig. 81.

Actinocyclus oculatus Jousé, 1968, p. 18, pl. 2, figs. 6, 7; Koizumi, 1973, p. 831, pl. 2, figs. 8,9

Azpeitia nodulifer (Schmidt), G. Fryxell, P.A. Sims, and T.P. Watkins, 1986, p. 19.
Bacteriastrum hyalinum Lauder, 1864, p. 8, pl. 3, fig. 7; Baldauf, 1984, p. 466, pl. 1, fig. 5 .

Bacterosira fragilis Gran, 1900, p. 114; Jousé, 1962, fig. 2, no. 15; Sancetta, 1982 , p. 227 , pl. 2, figs. 1-4.

Coscinodiscus asteromphalus Ehrenberg, 1844, in Hustedt, 1930, pp. 452 454 , fig. 250.

Coscinodiscus marginatus Ehrenberg, 1841, p. 142; Hustedt, 1930, p. 416, fig. 223.

Coscinodiscus radiatus Ehrenberg, 1839, p. 148, pl. 3, figs. 1a-c; Hustedt, 1930, p. 420, fig. 255.

Hemidiscus cuneiformis Wallich, 1860, p. 42, pl. 2, figs. 3, 4; Baldauf, 1984, p. 466 , pl. 1, figs. 6,7 .

Neodenticula seminae (Simonsen and Kanaya) Akiba and Yanagisawa, 1986, pp. 491, 492, pl. 24, figs. 1-11; pl. 26, figs. 1-10. Synonym: Denticula seminae Simonsen and Kanaya, 1961, p. 503, pl. 1, figs. 26-32; Denticulopsis seminae (Simonsen and Kanaya) Simonsen, 1979, p. 65.

Nitzschia bicapitata Cleve: Hustedt, 1958, p. 169, figs. 176-190; Hasle, 1960, p. 21, pl. 6, figs. 53-57.

Nitzschia fossilis (Frenguelli) Kanaya: Baldauf, 1984, p. 469, pl. 4, figs. 8, 10, 11, 14, 15; Akiba, 1986, p. 473, pl. 22, figs. 6-8.

Nitzschia marina Grunow; Baldauf, 1984, p. 470, pl. 5, figs. 1, 2.

Nitzschia punduriformis Gregory, 1857, p. 529, fig. 57; Fenner, 1979, p. 525 , pl. 32, figs. 27-29; Baldauf, 1984, pl. 5, fig. 8.

Nitzschia reinholdii Kanaya; Baldauf, 1984, p. 469, pl. 4, figs. 5-7; Akiba, 1986, p. 473, pl. 22, figs. 4-5.

Proboscia alata Sundström, 1986, pp. 99-102, pl. 36, figs. 258-266. Synonym: Rhizosolenia alata Brightwell, 1858, p. 95, pl. 5, figs. 8, 8a.

Proboscia curvirostris Jordan and Priddle, 1991, p. 57. Synonym: Rhizosolenia curvirostris Jous, 1959, p. 48, pl. 2, fig. 17; Akiba and Yanagisawa, 1986 , p. 497 , pl. 42, figs. 1 , 2; pl. 45, figs. $1-6$

Pseudoeunotia doliolus (Wallich) Grunow, in Van Heurck, 1881, pl. 35, fig. 22; Baldauf, 1984, pl. 5, figs. 5-7.

Rhizosolenia bergonii Peragallo: Hustedt, 1930, p. 575, fig. 327; Koizumi and Tanimura, 1985, p. 300, pl. 6, fig. 14.

Rhizosolenia hebetata forma hebetata Sundström, 1986, pp. 47, 48, pl. 4, figs. $18 \mathrm{a}, \mathrm{b}$; pl. 17, figs. 112, 113.

Rhizosolenia hebetata forma semispina (Hensen) Gran, 1904, p. 524, pl. 17; Sundström, 1986, pp. 48-52, pl. 4, figs. 19, 20; pl. 17, figs. 117, 118.

Rhizosolenia setigera Brightwell: Hustedt, 1930, p. 588, fig. 336.

Rhizosolenia styliformis Brightwell, 1858, p. 95, pl. 5, figs. 5a, b, d; Baldauf, 1987, pl. 6, fig. 7.

Roperia tesselata (Roper) Grunow: Hustedt, 1930, p. 524, fig 297.

Stephanopyxis turris (Greville and Arnott) Ralfs in Pritchard, 1861, p. 826, pl. 5, fig. 74; Schrader and Fenner, 1976, pl. 30, figs. 1-10, 14; pl. 37, figs. 17-19.

Thalassionema nitzschioides (Grunow) Van Heurck, 1896, p. 319, fig. 75; Schrader and Fenner, 1976, pl. 5, fig. 8.

Thalassiosira antiqua (Grunow) Cleve Euler: Akiba, 1986, p. 463, pl. 12, figs. $1,3-4$.

Thalassiosira eccentrica (Ehrenberg) Cleve: Fryxell and Hasle, 1972, p. 297, pl. 1-4, figs. 1a-18.

Thalassiosira gravida Cleve, 1896, p. 12, pl. 2, figs. 14-16; Hustedt, 1928, p. 325, fig. 161; Schrader and Fenner, 1976, pl. 16, figs. 5, 6; pl. 17, fig. 2.

Thalassiosira jouseae Akiba, 1986, p. 457, pl. 6, figs. 8-10.

Thalassiosira lineata Jousé: Hasle and Fryxell, 1977, p. 22, figs. 15-25.

Thalassiosira nidulus (Tempére and Brun) Jousé, 1961, p. 63; Akiba, 1986, p. 457, pl. 6, figs. 4-7.

Thalassiosira nordenskioeldii Cleve, 1873, p. 7, pl. 1, fig. 11; Hustedt, 1928, p. 321, fig. 157; Sancetta, 1982, p. 242, pl. 5, figs. 8-9.

Thalassiosira oestrupii (Ostenfeld) Proshkina-Lavrenko, 1949; Hasle, 1960 p. 8, pl. 1, figs. 5-7; Akiba, 1986, pl. 14, figs. 1-6.

Thalassiosira trifulta Fryxell, in Fryxell and Hasle, 1979, p. 16, pls. 1-5, figs. 1-24; Sancetta, 1982, p. 244, pl. 5, figs. 10-12.

Thalassiothrix longissima Cleve and Grunow, 1880: Hustedt, 1932, p. 247, fig. 726; Hasle and Semina, 1987, figs. 1-25. 


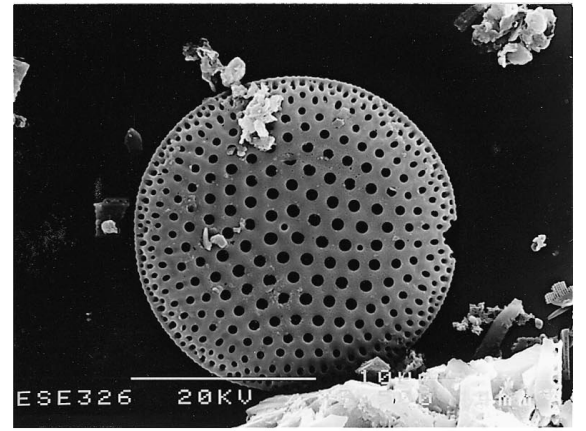

1

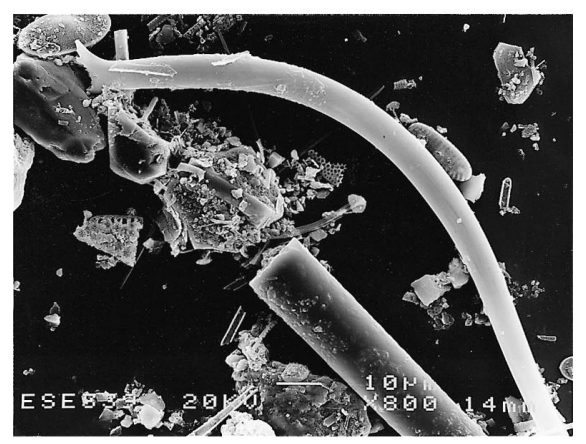

4

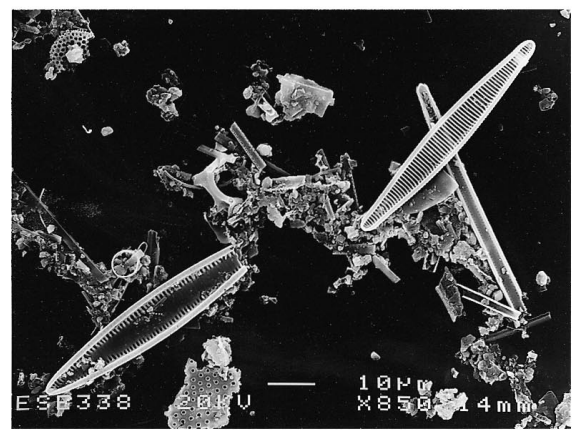

7

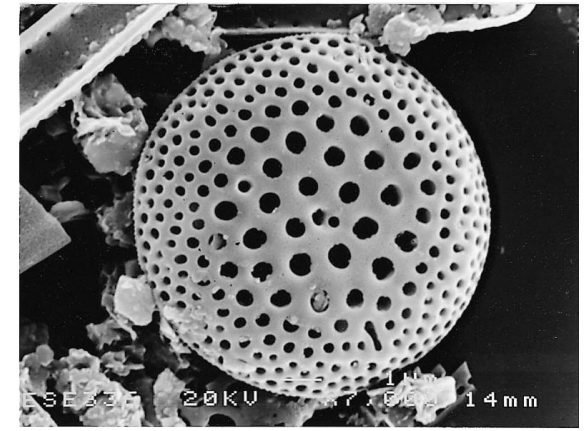

2

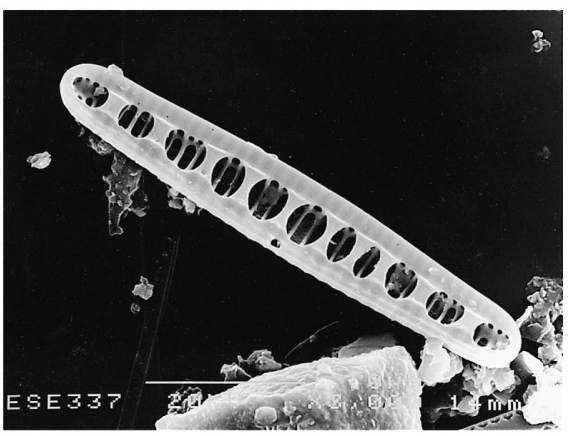

5

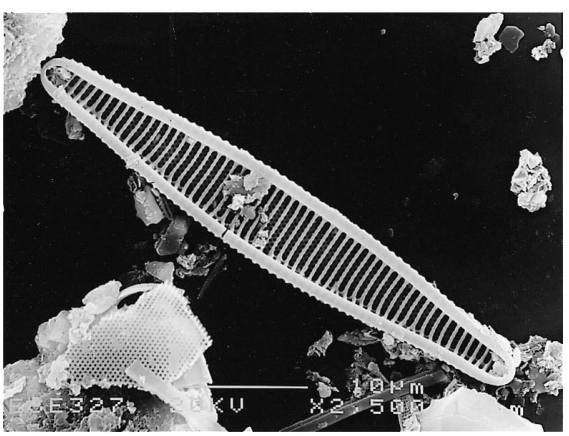

8

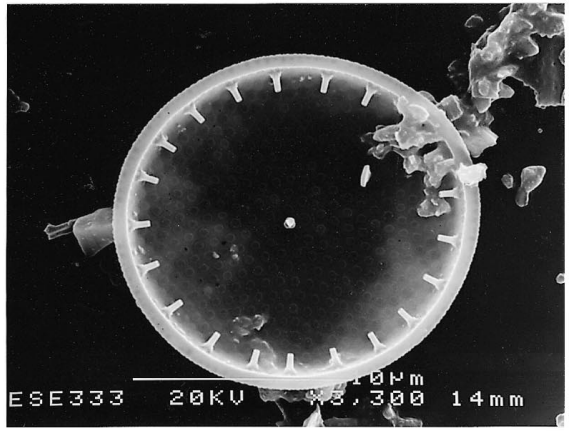

3

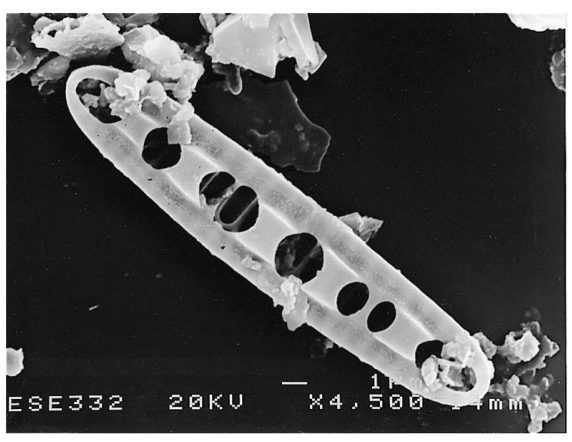

6

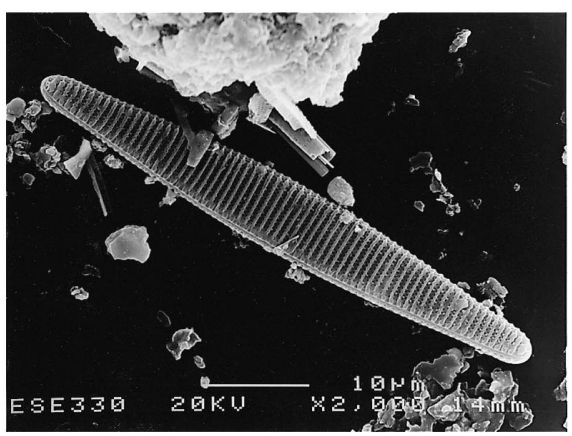

9

Plate 1. Scale bar $=10 \mu \mathrm{m}$ unless otherwise indicated. All are scanning electron microscope (SEM) pictures from Sample 162-983A-13H-7, 49-50 cm. 1, 2. Thalassiosira oestrupii (Ostenfeld) Proshkina-Lavrenko, external views of valve face with a central process and a labiate process halfway between the center and the margin. 3. Thalassiosira oestrupii (Ostenfeld) Proshkina-Lavrenko, internal view of valve face with a row of marginal spines, with a central process and a labiate process halfway between the center and the margin. 4. Proboscia curvirostris Jordan and Priddle. 5. Neodenticula seminae (Simonsen and Kanaya) Akiba and Yanagisawa, internal view of valve face. 6. Neodenticula seminae (Simonsen and Kanaya) Akiba and Yanagisawa, internal view of valve face. Scale bar $=1 \mu \mathrm{m}$. 7. Nitzschia reinholdii Kanaya and Koizumi, at lower left, and Nitzschia fossilis (Frenguelli) Kanaya, at top right. 8. Nitzschia fossilis (Frenguelli) Kanaya, internal view. 9. Nitzschia fossilis (Frenguelli) Kanaya, external view. 


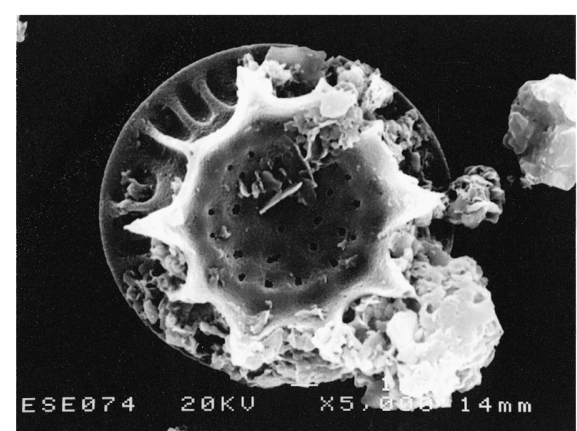

1

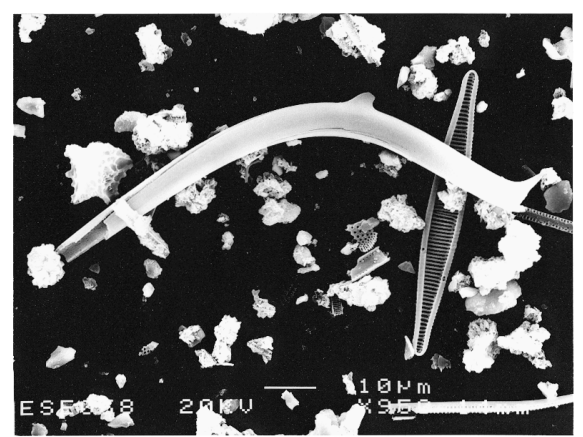

4

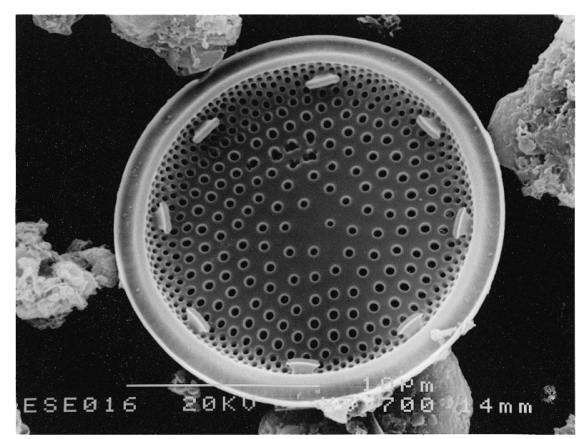

7

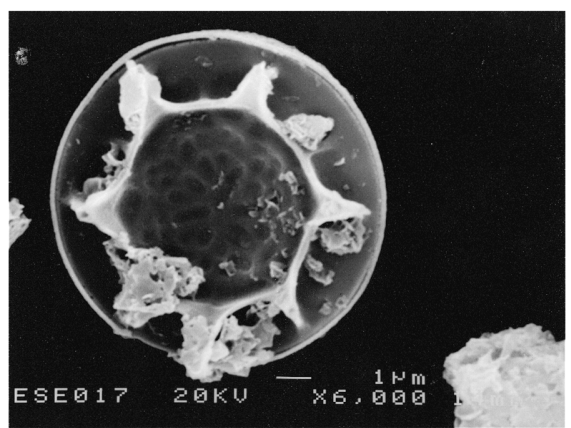

2

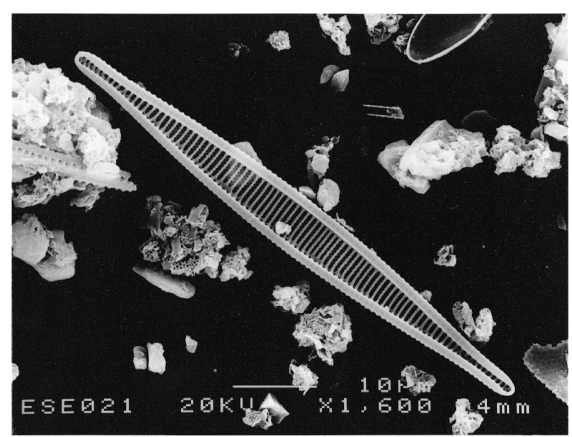

5

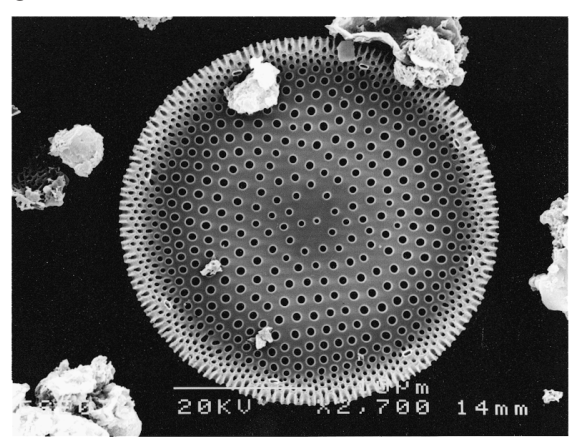

8

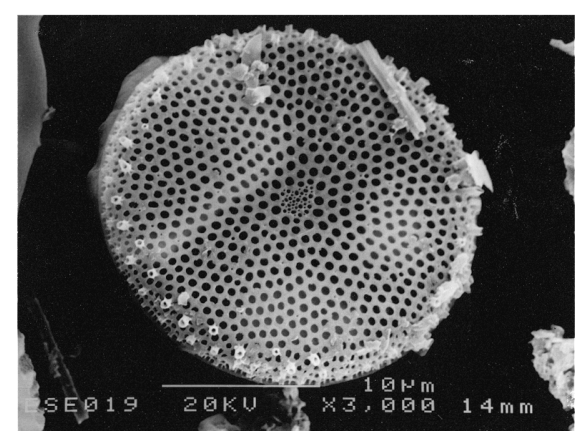

3

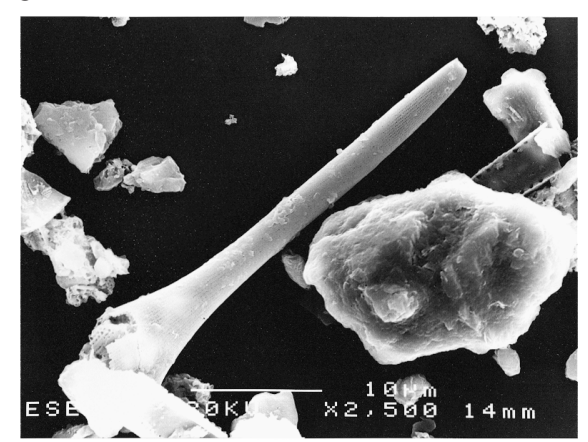

6

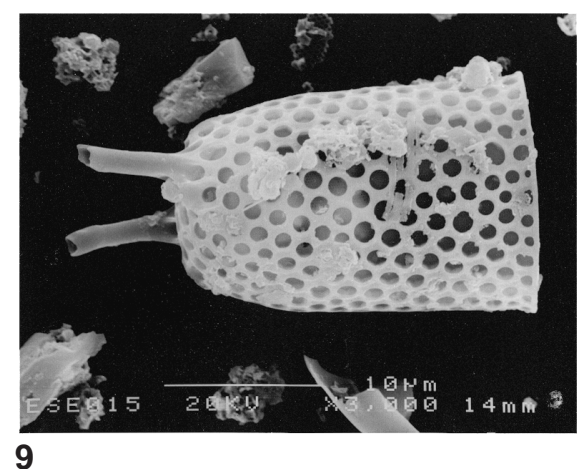

Plate 2. Scale bar $=10 \mu \mathrm{m}$ unless otherwise indicated. All are SEM pictures. 1, 2. Thalassiosira jouseae (Akiba), Sample 162-983A-27H-7, 49-50 cm. 3. Thalassiosira gravida (Cleve), vegetative cell, Sample 162-983A-9H-3, 49-50 cm. 4. Proboscia curvirostris (Jordan and Priddle) and Nitzschia fossilis (Frenguelli) Kanaya, Sample 162-983A-9H-3, 49-50 cm. 5. Nitzschia fossilis (Frenguelli) Kanaya, Sample 162-983A-9H-3, 49-50 cm. 6. Proboscia alata (Sundström), Sample 162-983A-9H-3, 49-50 cm. 7. Actinocyclus oculatus (Jousé), internal view, Sample 162-983A-27H-7, 49-50 cm. 8. Actinocyclus oculatus (Jousé), external view, Sample 162-983A-27H-7, 49-50 cm. 9. Stephanopyxis turris (Greville and Arnott), Sample 162-983A-27H-7, 49-50 cm. 